Article

\title{
Sustainable Development and Resilience: A Combined Analysis of the Cities of Rotterdam and Thessaloniki
}

\author{
Theodore Metaxas ${ }^{1, * \mathbb{C}}$ and Stella Psarropoulou ${ }^{2}$ \\ 1 Department of Economics, University of Thessaly, 38333 Volos, Greece \\ 2 Resilient Thessaloniki Office, 54636 Thessaloniki, Greece; stellapsar@gmail.com \\ * Correspondence: metaxas@uth.gr; Tel.: +30-2421-074-917
}

Citation: Metaxas, T.; Psarropoulou, S. Sustainable Development and Resilience: A Combined Analysis of the Cities of Rotterdam and

Thessaloniki. Urban Sci. 2021, 5, 78

https://doi.org/10.3390/

urbansci5040078

Academic Editor: Stella Sofia Kyvelou

Received: 29 June 2021

Accepted: 1 September 2021

Published: 14 October 2021

Publisher's Note: MDPI stays neutral with regard to jurisdictional claims in published maps and institutional affiliations.

Copyright: (c) 2021 by the authors. Licensee MDPI, Basel, Switzerland This article is an open access article distributed under the terms and conditions of the Creative Commons Attribution (CC BY) license (https:// creativecommons.org/licenses/by/ $4.0 /)$.

\begin{abstract}
The concept of a resilient city and its relationship with sustainable development has already received wide attention among academics, practitioners, and decision-makers, especially in the last decade. For many scholars, resilience is one of the concepts of sustainable development, in the sense that even more sustainability is an essential goal for development, and resilience is a way of thinking and acting that would lead us towards achieving sustainability. Moreover, resilience is about building and planning to future-proof cities. Resilience is a process that represents a new way of thinking, determining which urban challenges and crises have the lowest impact, and also building back better and evolving. The main aim of this study is to identify the potential relationship between sustainable development and resilience by using the Espiner et al. model. The model, which was created in reference to nature-based tourism destinations, suggests that the relationship between sustainability and resilience in tourism can be illustrated by three potential states: emergent, developing, and mature. In the present study, we adapt these potential states in case studies of the cities of Rotterdam (the Netherlands) and Thessaloniki (Greece), in order to demonstrate whether they are emergent, developing, or mature, by examining the critical documents of the (a) City Resilience Framework, and (b) Resilient Strategy Reports for Thessaloniki and Rotterdam, respectively.
\end{abstract}

Keywords: sustainable development; resilience; comparative analysis; city resilience framework

\section{Introduction}

The postmodern period, especially after 1980, is characterized by a variety of multidimensional factors that affect places and mainly cities in Europe and internationally in many different ways. Globalization, rapid technology, economic crises, de-industrialization, urbanization, and European enlargement combined with crucial geopolitical issues led European cities to seek new development models [1-6]. Regions and cities, especially in recent decades, have faced many challenges and chronic stresses, such as poverty, economic and social inequality, climate change, and pandemics that affect urban dwellers, in addition to challenges to infrastructure and the basis of their urban fabrics [7-11]. Thus, recent interest in sustainable development as a broader umbrella for urban planning and resilience has been raised in scholarly discourse. Following Espiner et al. [12], in the academic discourse, conceptualizing resilience and sustainability is complex and at times confusing. Both have been used to interpret components of social, economic, and environmental maintenance in destination communities, and at initial inspection, the ideals appear compatible. Several studies from different disciplines have tried to create the connection between them. Ahern [13] discusses a suite of strategies intended to build urban resilience capacity in the contest of resilience theory and sustainability science. Romero-Lankao et al. [14] focuses on what capacities urban actors draw on to create sustainability and resilience, while Cartalis [15] concludes that the concept of resilience adds a new perspective to the issue of sustainability in the sense that resilience is needed for a sustainable environment. Based on primary data, Bec et al. [16] examine community resilience frameworks to guide regional 
development and sustainable society. In a similar position, Saunders and Becker [17] reference resilience and sustainability within a land use planning and natural hazard context, suggesting that a resilient community should also be a sustainable community, not only to meet legislative requirements, but also, more importantly, to ensure that the economic, social, cultural, and environmental needs of future generations are met.

During the COVID-19 pandemic, urban resilience was at the forefront of a process of mitigation, adaptation, and recovery from all the unprecedented impact. Thus, resilience is about building and planning to future proof cities. It is a process, and it represents a new way of thinking, determining how urban challenges and crisis can have the lowest impact and actually build back better. In the Section 1, we focus on the concepts of sustainable development and resilience in order to identify the potential relationship between them by using the Espiner et al. [12] model. This model, in reference to nature-based tourism destinations, suggests that the relationship between sustainability and resilience in tourism can be illustrated as three potential states: emergent, developing, and mature. In the present study, we adapt these potential states in case studies of the cities of Rotterdam (The Netherlands) and Thessaloniki (Greece), in order to demonstrate whether their levels of resilience can be said to be emergent, developing, or mature. The Section 3 of the study presents the combined methodology and research questions while the Section 4 focuses on the two cases studies and presents the results of the combined analysis, while the last section, the Section 5 , includes our conclusions and the answers to the research questions.

\section{Sustainable Development and Resilience}

\subsection{Sustainable Development}

The 'Report of World Commission on Environment and Development: Our Common Future', [18] the so called, 'Brundtland Report' first mentioned the notion of sustainable development in 1987. Sustainable development was defined as "the development that meets the needs of the present without compromising the ability of future generations to meet their own needs" $[19,20]$, and social development within the constraints of the life support systems of the planet.

Following the analysis of Robert et al. [20], sustainable development came into the discourse again in 2015, where the UN, within the framework of the Urban Agenda (HABITAT III), launched the 17 sustainable development goals (SDGs) with numerous indicators to be measured. The SDGs could be considered as an international prototype of sustainable development adapted to their unique characteristics, weaknesses, and strengths on national, regional, and local levels [21]. That is the reason why sustainable development could be identified as a broader comprehensive concept that comprises ecological, economic, and social dimensions and action with other notions or designations such as the "resilient" city, the "eco" city, the "smart" and "intelligent" city, the "knowledge" city, and so on [22]. Jeffrey Sachs [23], in his book The Age of Sustainable Development, which was adopted by the UN General Assembly, describes and analyses the perspectives and the principles of sustainable development in light of the SDGs. For Sachs [23], sustainable development is "both a way of understanding the world and a method for solving global problems" and he supports and a fourth objective or pillar: governance. Additionally to the environment, social cohesion, and the economy, governance plays a key role in the complexity of the system of sustainable development. The complexity of a system provokes many misinterpretations along with the difficulty in passing from academic notion to practical implementation [24]. For example, when the banks failed in 2008, the whole world faced an unexpected economic crisis with multiple effects. A complex system demands a complex way of thinking. Sustainable development can be considered as a tool to prototype and normalize that which brings well-being to citizens. It is not an easy goal to implement on the international, national, or local levels. Urban sustainability arises from these norms, and it requires a holistic approach to being addressed, as it requires not only urban planning but also the engagement of the local government and local community (stakeholders and civil society) [23]. 


\subsection{Resilience}

Accordingly, the term of resilience is not another concept to replace sustainability but is another concept that needs to intersect with the sustainable development, the urban planning, and the image of a region/city. Nevertheless, resilience has been for more than ten years in the scholar discourse and widespread in urban thinking and planning [25]. Many different definitions have been given with a diversity of scientific approaches and many different studies related to resilience [24]. Some academics think that resilience is a buzzword as there is an ambiguous transformation from theory to practice or there is no consensus on the common principles and methodologies in order to measure the progress on resilience [24-26]. Resilience is mostly related to climate change and the environmental perspective (EU perspective), or in risk reduction (America's perspective) [24], yet resilience imposes on many scientific areas and it is commonly accepted as a concept and a way of thinking that imposes on the "global mandate of urban competiveness and has a more urgent and consensual character" [27]. Coming from the Latin word "resiliere", which means rebound and retreat [28], the academic literature claims two perspectives of resilience: the "bouncing back" and the "bouncing forward"; however, the COVID-19 pandemic has given rise in particular to the "build back better" framework. Primary was met in psychology, where resilience is the ability to recover from a shock, to be met later over an ecological framework, in which Walker et al. [29] define resilience as "the capacity of a system to absorb disturbance and reorganize while undergoing change so as to still retain essentially the same function, structure, identity, and feedbacks". That is claimed to be the engineering perspective, according to which, in a stable ecosystem (region/city), if a shock or a crisis occurs, then the system tends to bounce back to an equilibrium situation. In contrast, under the ecological perspective, the ecosystem (region/city) following a crisis or a shock comes to another state and impacts on the ecosystem's (region/city) behavior [28]. Nevertheless, the aforementioned two perspectives of resilience cannot be applicable for urban planning and functions because cities are complex and dynamic systems with multiple interconnections among the urban ecosystem and assets [30].

According to Stefano Capolongo et al. urban resilience should be a long-term strategic planning and management and not just a "tactical approach" to each crisis or incident [31]. In this case, resilience it is considered more as a process rather than a characteristic of a place [32] that should activate and encourage citizens to use and advocate open green spaces and emphasizes to policymakers the move from strategic planning to strategy implementation [31] and monitoring. Moreover, D'Amico, A. et Currà, E point out, the implementation of urban resilience needs to loop through different components of a city [33]. In another perspective, the notion of resilience was mentioned due to hurricane Katrina (New Orleans, USA) and then linkages to climate change (mitigation and adaptation), social inclusion, and the economic crisis were created [22]. Thus, many cities try to develop resilient strategies or adopt tools and methods that could enhance their resilience way of thinking and planning and in order to structure new urban policies. Several organizations and initiations of cities' networks have been established to make the resilience thinking process more robust and to aid cities and regions to exchange knowledge and technical assistance [25]. Those are ICLEI, the Asian Cities Climate Change Resilience Network (ACCCRN), the Resilient Cities Network (former 100 Resilient Cities) and other initiatives [34,35].

Overall and with the last definitions of resilience, there is a need to justify the aforementioned literature review. It is more important to clarify that resilience has multiple meanings. However, it cannot mean everything. It also has a theoretical approach under the ecological framework and a theoretical attempt to be applied on socio-economic systems as cities [36]. However, this application is not unproblematic because, as Davoudi and Porter [37] point out, "in applying an ecologically rooted concept to the social setting, we need to tread carefully and ensure that in trying to understand society through the lens of ecology we do not lose the insights from critical social science." 
Summing up, the concept of resilience is more or less a way of thinking that requires effective and smart application on each city's fabric, specific characteristics, needs and values. Taking, for example, all the work provided over the past six years by the Resilient Cities Network (former 100RC-pioneered by Rockefeller Foundation since 2014) to the member-cities of different sizes, history, culture, needs, and stage of development world widely, we can surely understand that resilience is not just an on-off procedure. Nevertheless, it is a process that allows each city to develop a strategic plan in responding, adapting, and evolving under unprecedented circumstances and constant transformations of its ecosystem. Resilience provides to decision-makers a way of working, cooperating, and interconnecting either at an institutional level or at a social level [30]. However, Davoudi and Porter [37] indicate a cautionary note on the resilience theory, suggesting that there is a thin dividing line not to become the resilience a buzzword, but it is argued that the impact of resilience in urban planning is substantial because it can shape the challenges and also respond to them. Finally, Walker and Salt [38] suggest a three-step framework to understand resilience thinking. The first step is to assess and understand how the world works (or how a specific city works). The second one is to understand that the system of a city is as a complex adaptive system, and the last step is the willingness and initiatives taken to improve the adaptability and transformation of the city's system through collaborative and targeted processes [38].

Coming to the interrelation of sustainable development and resilience, from their point of view, Espiner et al. [12] with particular reference to nature-based tourism destinations, support that the relationship between sustainability and resilience in tourism can be illustrated as three potential states: emergent, developing, and mature. Their model derives from the argument that the most sustainable destinations are those with high levels of resilience. It is illustrated that resilience is necessary but not sufficient for sustainable development and it should intersect with sustainability even it is conceptually separate. Following this model, when destinations lack resilience, they belong to "emergent' state, meaning that the sustainability of the tourism system is most vulnerable to any perturbations associated with the environment, economy and society [12]. On the other hand, destinations (or specific businesses) where resilience is more developed, covering and coping with a wider range of potential exposure scenarios, can create an important intersection with sustainability and illustrated as the "mature" state. However, the "mature" state of the relationship — where all elements of resilience overlap with sustainability—is theoretically attractive.

Consequently, the resilience has diverse parameters and can be applied in many sectors of a city's life. However, resilience should be considered as an ongoing process rather than a target of a "resilient city" concept.

In conclusion, it is important to mention that many researchers do not agree that sustainability and resilience are two different perspectives. Instead, it is common that resilience and sustainability are essentially the same $[39,40]$ or that resilience is an essential indicator of sustainability, or that sustainability is the broad social goal and resilience is how it can be implemented [39,40]. Ultimately, resilience is considered key in achieving long-term sustainability in urban social-political and socio-ecological systems [14].

\section{Methodology and Research Questions}

\subsection{A combined Methodology}

The current study adapts a combined methodological approach. Firstly, a case study analysis. The case study is a very common technique [41-46]. Following the City Resilience Framework [47], case study is "a performance-based approach, which defines resilience in terms of a city's ability to fulfil and sustain its core functions, offers a more comprehensive and holistic approach". As a city's functions rely on a combination of assets, systems, practices, and actions undertaken by multiple actors, a performance-based approach has greater potential to address questions of interdependency, power dynamics, and scale. 
This study uses the cases of Thessaloniki (Greece) and Rotterdam (The Netherlands). The selection of these cases is not random, the two cities are members of the Resilient Cities Network, they are both major port cities in Central and South Europe and they are medium-sized cities according EU standards. In addition, both cities belong to countries that present high levels of poverty and social exclusion in Europe for the period 2009-2017 caused by the economic crisis 2008-2009. Ultimately, from a different perspective of resilient thinking, both of the cities have managed to use resilience as a robust for further sustainable development.

Secondly, content analysis is applied. Woodrum [48] stated that the special potential of content analysis is its explicit linkage of qualitative symbol usage with quantitative data and the fact that category construction is simply another form of concept operationalization that is well known to research designers. Krippendorf [49] mentions that content analysis is a research technique for making replicable and valid inferences from texts (or other meaningful matters) to the context for their use. A previous but similar definition considers content analysis as "a technique for objective, systematic, and quantitative description of the manifest content of communication" [50]. For Handayania et al. [51], content analysis is crucial to capture the inferences and logic of interpretation from selected documents. Regarding content analysis, has been used to several cases related to resilience and sustainability analysis [48-51]. In this study, the critical documents are the following: (a) City Resilience Framework (47), (b) Resilient Strategy Reports for Thessaloniki and Rotterdam.

Finally, a comparative analysis is applied. Comparative analysis is also a well-known methodology process for many research areas including resilience and sustainability [52-57]. Comparative analysis needs to be separated from the sense in which all analysis is comparative: all attempts to find causes involve comparing what happened with a mental image of what is likely to have happened in the absence of certain features [54]. In addition, comparative case studies involve the analysis and synthesis of the similarities, differences, and patterns across two or more cases that share a common focus or goal. To be able to do this well, the specific features of each case should be described in depth at the beginning of the study [55]. At long last, by adapting the model of Espiner et al. [12] mentioned above, the study applies this model to the two cases studies based on the analysis of them.

\subsection{Research Questions \\ Q1: Does resilience constitute an easy task? \\ Q2: What are the main differences between the two studied cities? \\ Q3: Is sustainable development achieved via resilience, or the opposite?}

\section{Examples from Rotterdam and Thessaloniki}

As mentioned earlier, resilience can be applied in many different scientific fields; however, for an urban complex system, resilience is defined as the way an urban ecosystem reacts to and is maintained in a disturbance, adapts but also transforms and evolves in all aspects. Therefore, resilience includes spatial planning, urban development, and adaptation, and interrelates with all the components of an urban system such as the environment, economy, and society [22,30]. Thus, resilience is embedded in the sustainable development concept.

The choice of Rotterdam and Thessaloniki was made because both of them are members of the Resilient Cities Network and they have developed a resilient strategy based on the City Resilience Framework (CRF) tool [47]. The CRF is a tool that was developed by ARUP, pioneered by the Rockefeller Foundation, and helps to better understand the multiple dimensions that compose a city's resilience. CRF was used during the assessment and development of each city's strategic plan for the diagnosis of problematic areas and to recognize opportunities of improvement.

According to Figure 1, CRF is imprinted as a wheel that comprises four categories, twelve goals, and seven qualities. "City resilience is complex. The three layers of the City Resilience Framework-categories, goals and qualities-each contribute to a richer articulation of 
resilience. The framework can be used to facilitate a common understanding of resilience amongst diverse stakeholders. It can also be used to identify where there are critical gaps, where action and investment to build resilience will be most effective, or where deeper analysis or understanding is required" [47].
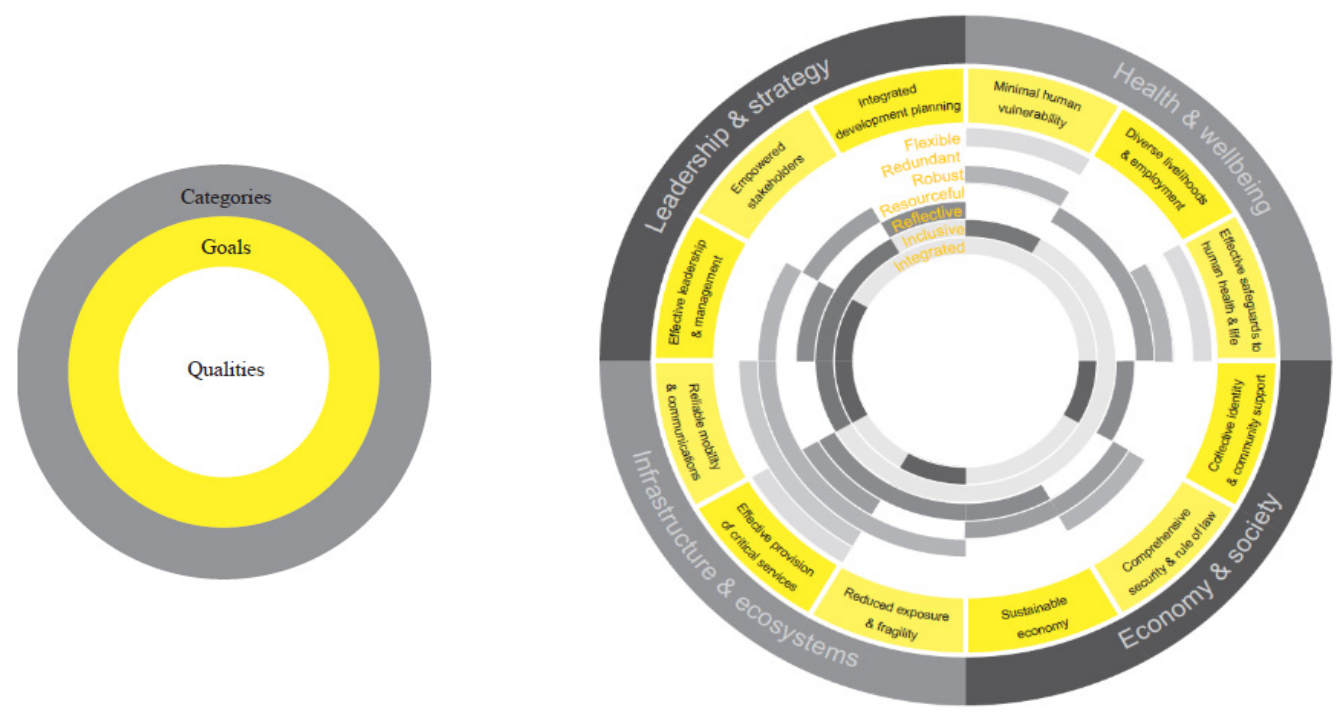

Figure 1. The complex character of city resilience.

According to the CRF tool, Rotterdam and Thessaloniki analyzed their city's components and exploited the discovery areas that lead to each city's values, vision, goals, and objectives. Taking into consideration both of the strategies, we made a content and comparative analysis, in order to conclude why Thessaloniki's resilient image should be identified as "emergent" and Rotterdam's as "mature" according to Espiner et al.'s [12] model mentioned above.

Thus, content and comparative analysis is conducted upon: (a) vision, (b) goals with a timeline till 2030, (c) focus areas and challenges, (d) city's values, (e) implementation examples, and (f) CRF results.

Firstly, it is important to point out that both cities are second-tier (according to the SGPTD Final Report, ESPON, 2012, second-tier cities are defined as "those cities outside the capital whose economic and social performance is sufficiently important to affect the potential performance of the national economy. It does not imply that they are less important than the capital cities. It certainly does not mean that they are second class. And it does not mean they are the 'second' city-because there is only one of these in each country. And second tier cities are not all the same-they vary enormously. Sometimes they are very large regional capitals. Sometimes they are the second largest city of the country with huge national significance-for example Barcelona, Munich and Lyon in this study. But many are much smaller. However, while they differ in many respects, second tier cities can play comparable national economic roles." In this report, Thessaloniki and Rotterdam are among the studied cities [58]) with common geographical and demographic characteristics despite the economic growth and capability. Specifically, Rotterdam is the second biggest city in the Netherlands with 651.446 population, but it influences more than 2 million in a region level along with The Hague. Rotterdam's economy is strongly connected to the water [59] and it is Europe's largest seaport. Thessaloniki is also a secondtier port city, the second biggest city in Greece, with a 2300 year history. Municipality's population is 324,766 people (2011 census), although it is considered to influence the whole region of Central Macedonia and approximately 1.9 million people [60].

\subsection{Content and Comparative Analysis Outcomes}

Table 1 imprints the content analysis based on both resilient strategies and especially on the vision, goals, focus areas and challenges, and values of each city. 
Table 1. Content analysis on resilient strategies of Rotterdam [59] and Thessaloniki [60].

\begin{tabular}{|c|c|c|}
\hline Areas & Rotterdam & Thessaloniki \\
\hline Vision & $\begin{array}{l}\text { IN 2030, ROTTERDAM WILL BE A CITY WHERE: Strong citizens } \\
\text { respect each other and are continuously developing themselves, the energy } \\
\text { infrastructure provides for an efficient and sustainable energy supply in } \\
\text { port and city, climate adaptation has penetrated into mainstream of city } \\
\text { operations and water has added value for the city and our water } \\
\text { management system is cyber-proof, the underground is being used in } \\
\text { such a way that it supports the growth and development of the city, we } \\
\text { have embraced digitization without making us dependent, and we have } \\
\text { ensured a best practice level of cyber-security, self-organization in the city } \\
\text { has enough room and a flexible local government supports if really } \\
\text { needed; resilience is part of our daily thinking and acting. }\end{array}$ & $\begin{array}{l}\text { "Thessaloniki, an inspiring dynamic coastal city that } \\
\text { ensures the well-being of its people, nurtures its human } \\
\text { talent while strengthening its urban economy and } \\
\text { respecting its natural resources." }\end{array}$ \\
\hline Goals & $\begin{array}{ll}\text { 1. } & \text { Rotterdam: a balanced society; } \\
\text { 2. } & \text { World port city built on clean and reliable energy; } \\
\text { 3. } & \text { Rotterdam Cyber Port City; } \\
\text { 4. } & \text { Climate-resilient Rotterdam to the next level; } \\
\text { 5. } & \text { Infrastructure ready for the } 21 \text { st century; } \\
\text { 6. } & \text { Rotterdam Network city-truly our city } \\
\text { 7. } & \text { Anchoring resilience in the city }\end{array}$ & $\begin{array}{l}\text { 1. Shaping a thriving and sustainable city with } \\
\text { mobility and city systems that serve its people } \\
\text { 2. Co-creating an inclusive city that invests in its } \\
\text { human talent } \\
\text { 3. Building a dynamic urban economy and } \\
\text { responsive city through effective and networked } \\
\text { governance } \\
\text { Re-discovering the city's relationship with the } \\
\text { sea-Integrated Thermaikos Bay }\end{array}$ \\
\hline $\begin{array}{l}\text { Focus areas- } \\
\text { challenges }\end{array}$ & $\begin{array}{ll}\text { 1. } & \text { Social cohesion and education } \\
\text { 2. } & \text { Energy transition } \\
\text { 3. } & \text { Climate adaptation } \\
\text { 4. } & \text { Cyber use and security } \\
\text { 5. } & \text { Critical infrastructure } \\
\text { 6. } & \text { Changing urban governance }\end{array}$ & $\begin{array}{l}\text { 1. Thermaikos Bay: bringing water in the everyday } \\
\text { 2. Creating an ecosystem that enables human talent } \\
\text { 3. Co-ownership of public space } \\
\text { 4. Mobility as a driver for change } \\
\text { 5. Data empowered city }\end{array}$ \\
\hline $\begin{array}{l}\text { Values of the } \\
\text { city }\end{array}$ & $\begin{array}{l}\text { 1. } \begin{array}{l}\text { REFLECTIVE: using past experience to inform future } \\
\text { decisions }\end{array} \\
\text { 2. } \\
\text { RESOURCEFUL: recognizing alternative ways to use } \\
\text { resources, } \\
\text { ROBUST: well-conceived, constructed, and managed } \\
\text { systems, }\end{array}$ & $\begin{array}{l}\text { 1. Social Cohesion: Fighting exclusion and } \\
\text { marginalization, creating a sense of belonging } \\
\text { and promoting trust. } \\
\text { Local Identity and Heritage: Acknowledging the } \\
\text { past, promoting local culture and giving citizens } \\
\text { space for expression. } \\
\text { Environmental Management: Providing good } \\
\text { quality of life while respecting the limits of our } \\
\text { natural resources } \\
\text { 4. Health and Well-being: ensuring all citizens can } \\
\text { meet their basic needs (food, water, shelter) and } \\
\text { have access to healthcare. } \\
\text { Youth Empowerment: Strengthening the skills of } \\
\text { our youth, empowering them to take effective } \\
\text { decisions, and play an active role in city life. } \\
\text { Multi-stakeholder Engagement: Inclusive and } \\
\text { constructive collaboration between all actors } \\
\text { involved in city decision-making } \\
\text { Technology Adaptation: Applying new and } \\
\text { smart technologies that support social, economic, } \\
\text { and cultural transformations, and serve the } \\
\text { interests of citizens and the public good. }\end{array}$ \\
\hline
\end{tabular}

Source: authors.

Taking into consideration Table 1 with the results of each city's CRF that were conducted during the preliminary phase, we come to the conclusion that both cities followed prominent participatory procedures with Rotterdam to have engaged 17 stakeholders and more than 200 people to have been involved with 24 platform partners and international experts with research and workshops on areas that required more attention. On the contrary, in Thessaloniki's resilience dialogue, almost 40 stakeholders and more than 2000 citizens participated over questionnaires, public events, working groups, and committees.

The CRF wheel gave both of the cities the discovery areas that concluded to the vision and the goals (Figure 2). Rotterdam used the values that have been identified from Arup's methodology and resilience index, while Thessaloniki used the values that are better suited to the city's identity and history. Comparing those CRF wheels, Rotterdam already implements many of the goals the tool defines. On the other hand, in Thessaloniki, 
the majority of people believe that a lot of these goals need to do better and identify "the city to be youthful, somewhat conservative, and lacking in environmental consciousness, but also outward facing and hospitable" [60].
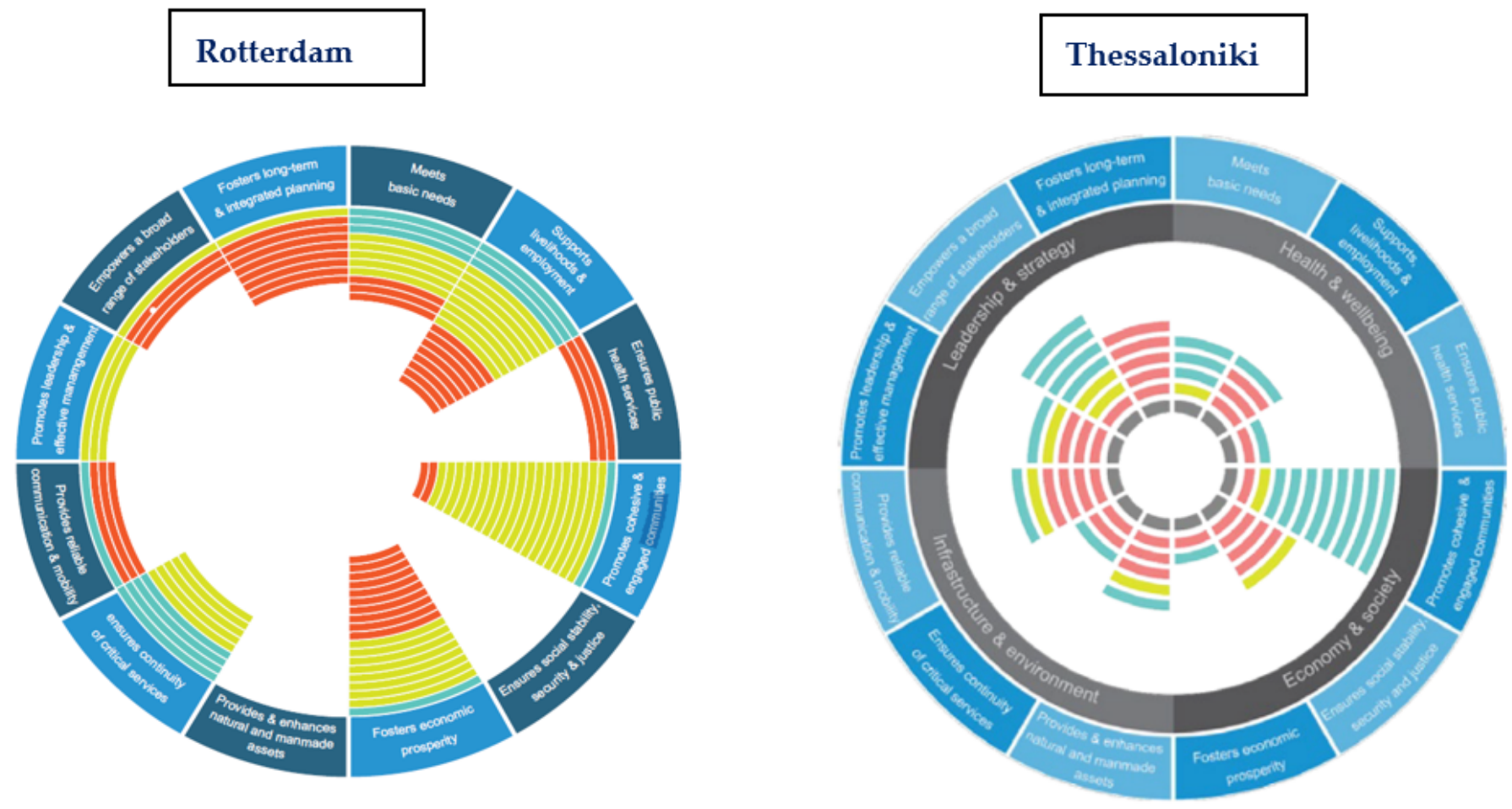

Area of strength

Doing well but can do better

Need to do better

Figure 2. CRFs of Rotterdam and Thessaloniki.

In general, Rotterdam considers this strategy as a "starting point" in order to encompass and enhance already existing projects, the sustainable development and to move from robustness to a resilient way of thinking and acting. For Rotterdam, the strategy was about learning to coordinate and live with water and how it can embed climate change into their daily lives, to thrive and enhance resilience as part of the city's identity and city's function.

On the other hand, Thessaloniki had, for the first time, a strategic document, developed by the city's fabric for the city's future. Resilience is about a new way of working, a new way of collaborating, planning, and sharing the responsibilities, opportunities, and common challenges that the city faces. It was more like a 'roadmap' to set guidelines for activities that could build resilience, unlike Rotterdam, which was more about establishing a resilient future beyond robustness.

According to the methodology of ARUP, to prepare each city, the strategy should follow at least three phases. Phase I is the assessment of the baseline, phase II is the development of the strategy, and phase III is the implementation. Both strategies have a timeline till 2030. That means that these documents are dynamic and need to be monitored, measure indicators, and update with new trends. Therefore, the implementation of these strategic documents could actually determine whether resilience is part of the marketing and the image of each city along with the interconnections with sustainability. A couple of examples from both Rotterdam and Thessaloniki on the implementation or the enhancement of resilience will allow us to explain why Rotterdam can be considered to be in 'mature' state while Thessaloniki is in 'emergent' according to the Espiner's [12] methodology. 
A first example of Rotterdam's strategy is its water squares, which were built in 2013 in the context of the Rotterdam water city 2035 program, and it is actually a useful open space that it can also restore rainwater during downpours [59]. The water squares are an example of climate-based solutions on urban planning with a resilient perspective which also encompasses economic and social activity. This example was used to enhance and build better on Rotterdam's resilient future.

Likewise, a project that raises the city's resilience is the "Bo.Tu" project. This project is about making the first "resilient district", by managing infrastructure and social cohesion to help people improve their daily life, access to education, employment, and affordable housing. The "Bo.Tu" project seeks to cope with the city's challenges such as immigration, climate mitigation, and adaptation, inclusiveness, and poverty. Therefore, this project interconnects the three pillars of sustainable development with resilient thinking and aspires to become a good practice to be replicated and applied from other cities in the world [25].

Unlike Rotterdam, Thessaloniki's strategy was the opportunity to start working with a robust and participatory approach in order to embed the resilience thinking within the context of the city coping with many chronic stresses and disoperation of the past. Due to phase III, the implementation of the city's objectives and the goals during the operation of the Resilient Thessaloniki office was the cooperation with the World Bank in three main projects that contributed to the institutionalization and establishment of the resilient thinking. The first one was the development of a masterplan for the redevelopment of the waterfront, pointing out projections under the three pillars of sustainable development, economic (and financial), environmental, and societal. The second and third were two projects that provoked resilience as a substantial asset to risk reduction and risk management. Building upon a continuity plan for emergency cases and an Open Risk data platform allowed citizens and stakeholders or local entities to connect with the municipality's operations and planning in an effort to reinforce awareness and preparedness on extreme events. Figure 3 depicts an event on 20 June 2017, which was held as a memorial to the catastrophic earthquake of 1978 in Thessaloniki.

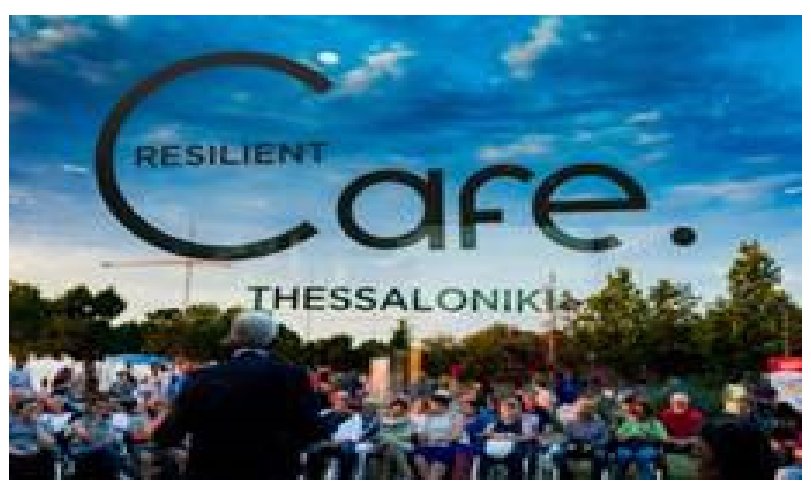

Figure 3. 20 June 2017-Resilient Day event. Source: Resilient Thessaloniki office archive.

Similarly, another example from the implementation process was a three-day international meeting (CoLab) conducted and funded by the 100RC and the municipality for the redevelopment of the Egnatia corridor after the construction of the Metro (Figure 4). It was one of the first international meetings with specific thematic but holistic representation of forty participants of local and international institutions (e.g., academia), firms (e.g., CISCO) and entities (e.g., real estate) to share a common vision and discuss innovative solutions and ideas for the redevelopment and refurbishment of the central corridor of the city. The importance of this project was the high participatory planning process that could lead decision-makers on common solutions and funding opportunities towards higher governmental levels. 

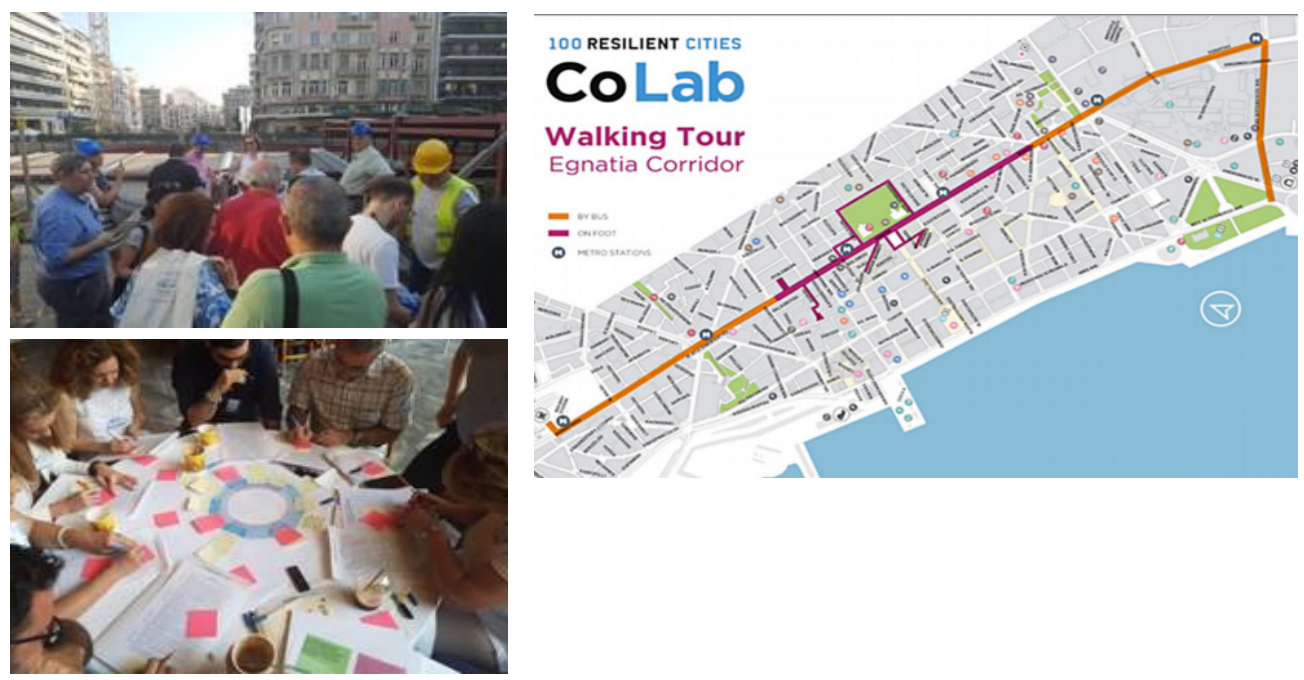

Figure 4. Colab June 2018-City Hall Thessaloniki. Source: Resilient Thessaloniki office archive.

The difference with Rotterdam was that Thessaloniki had to fight with many problematic situations starting with a rigid and conservative governmental apparatus. The main challenge of the city is conflicting jurisdictions, the lack of cooperation across the other governmental levels or the civil society, and consolidated operational and structural silos of the stakeholders of the city. The most important, fostered also by the economic crisis, was the lack of trust by citizens of the governmental operational goals and the denial of any participation [60]. Trying to benchmark Rotterdam's and Thessaloniki's past in resilience thinking, we should definitely result that they are two different perspectives that are influenced by the complexity of each city but mostly by the past experiences of the urban management and governmental function.

Consequently, by adapting the model of Espiner et al. [12], Thessaloniki can be defined as being in 'emergent' state, while Rotterdam is in 'mature' state.

\subsection{Mature vs. Emergent}

Rotterdam is in 'mature' state': Rotterdam, in its resilience strategy, defines resilience as a virtue of their residents because they are quite familiar to the notion of resilience, as they "were known for their vision, strength, courage and persistence" [59]. Rotterdam has managed several times to make water cases an opportunity and to be promoted as a climate adaptation living hub. However, their resilience strategy also acknowledges other stresses and puts the municipality in a more holistic approach including economic development and the civil society. Whilst strategic urban planning for climate adaptation and especially flooding have been developed since the mid-2000s, with this resilient strategy, Rotterdam's decision-makers wanted to suffuse holistically and to also consider chronic stresses and impacts on the economic and social life of this city. As mentioned to the strategic document [59]:

"Resilience thinking is being incorporated in the policymaking and initiatives across all domains of city government, including across social, physical and economic programs. These elements come together in "The Story of the City". The resilience strategy and "The Story of the City" are complementary. The latter sets out the kind of city we want Rotterdam to be, the Resilience Strategy shows how we can achieve this in a resilient way".

As Lu and Stead [61] report, planners and decision-makers of the municipality, eager to make the climate risk of the water an opportunity to enhance economic development and to promote the city as a climate adaptation pioneer and best practice to follow or invest. Moreover, the local authority's policies advance Rotterdam's competitiveness using as an image the based-climate readiness, strategic planning, and adaptation to flood risks. This indicates that many of Rotterdam's initiatives try to remark resilient thinking through 
climate-based solutions and puts it as a pioneer and expertise for other cities, creating a marketing image and a competitive advantage as well as a main competence [61].

Thessaloniki is in 'emergent' state: Resilient thinking is an ongoing process for Thessaloniki. Through all these years, Resilient Thessaloniki managed to gain a position in national and international press and to attract the funding and technical assistance of international or European institutions to help it incorporate urban development. As reported in the World Bank's blog: "Thessaloniki's strategy provides a roadmap for cities to make revitalization projects happen, from concept to implementation and financing" [62]. According to the first Deputy Mayor for Urban Resilience of the municipality, "in a city that is constantly changing, this strategy represents the start of a process of co-creation. A way to collectively work together, sharing responsibility, resources, opportunities and results" [60]. The resilient concept aided the image of the city of Thessaloniki as a paradigm of governmental transformation to more participatory procedures, embedding resilience thinking and adaptability cross-departmentally, cross-governmentally, and between the civil society of the city. As Pitidis and Coaffee [63] concluded:

"Thessaloniki's success in transforming entrenched governance traditions through the implementation of urban resilience should provide an example for other cities to proceed with further engagement of citizens in the decision-making processes $(\ldots)$ to avoid returning to the prior state on institutional inertia".

Thus, Thessaloniki tries to move to a new model of working by establishing synergies and collaborative trends with the civil society, and so it promotes an image of a resilient, youthful, multicultural, and inclusive European city [27,63,64].

\section{Conclusions}

In this article, we made an effort to clarify and point out the interrelations between the notions of sustainable development and resilience. We posed three research questions and we attempted to answer them by using the two examples Rotterdam and Thessaloniki as an aftermath of a literature review and a combined methodological approach.

Firstly, a case study analysis, by choosing the cases of Thessaloniki (Greece) and Rotterdam (the Netherlands). The selection of these cases is not random, the two cities are members of the Resilient Cities Network and both have managed to use resilience as a marketing image for further sustainable development. Secondly, content analysis is applied with the use of critical documents as (a) The City Resilience Framework (2014-2015), (b) The Resilient Strategy Reports for Thessaloniki and Rotterdam. Finally, a comparative analysis is applied by adapting the model of Espiner et al. [12] to the two case studies-Rotterdam and Thessaloniki-based on the analysis of them.

Attempting to answer our first research question, "Does resilience constitute an easy task?", we pointed out, from the two cases, that resilience could not be considered as a target or an on-off condition, but it is rather an ongoing process and needs to apply to many criteria within a city's fabric. Cities are dynamic complex systems, as was highlighted by COVID-19. So, urban resilience has a broader meaning that needs to include holistic perspectives and to prepare every element of a city that could have a direct or indirect impact [32], and thus, should interconnect other priorities as the Sustainable Development Goals, the disaster risk reduction, and the climate change, and should aim for decisionmakers to focus on solutions and responses in an integrated, inclusive, forward-looking manner. This is also advocated for on the Urban Agenda, as a mission and as a common vision for a sustainable future. To be more specific, according to the Urban Agenda's goals and targets for human settlements and cities, social inequality, economic growth with opportunities for everyone, the enhancement of participatory approaches, and the protection, restoration, and conservation of the ecosystems are initial and regards cities to be inclusive, resilient, and sustainable, leveraging productive and safe urban transformation [65].

Whilst, on the second question, "What are the main differences between the two studied cities?", the application of the model of Espiner et al. [12] showcased that Rotterdam is in "mature" state regarding resilient thinking to better adapt to climate change and learn how 
to live with water, whilst Thessaloniki is in "emergent" state as resilience is an ongoing process and it uses its strategic plan as a roadmap to set foundations of collaborations to build resilience for now and the future. Furthermore, for Rotterdam, resilience building means to better adapt to climate change, live with water, and move from robustness to a resilient future. On the contrary, for Thessaloniki, resilience building is more essential to the development of a strategic framework that could set foundations of collaboration and map the way from planning to acting and monitoring the impact on the ground.

Finally, to answer our last research question, "Is sustainable development achieved via resilience, or the opposite?", although it is a complex question that cannot be answered by only two case studies and consists of a contemporary theme that needs to be further assessed and discussed, we came to a primary assumption that sustainable development should be considered as an umbrella that embeds different concepts according to the era, the circumstances, and the localities of a place, such as the "resilient" city or the "smart" city, and so on. Resilience is substantial in urban planning and the urban managers not only to cope with the uncertain and chronic stresses and universal urban challenges, but also to "build back better" and to future-proof the places [24,61]. However, many researchers do not agree that sustainability and resilience are two different perspectives. Instead, it is common that resilience and sustainability are essentially the same $[30,39]$ or that resilience is an essential indicator of sustainability, or that sustainability is the broad social goal and resilience is how it can be implemented [29,32]. However, at the long end, as it is well accented to the Urban Agenda's implementation plan; sustainable development and resilience should complement each other and connect and be part of the urban policies as a way to thing over how our cities are built or identify vulnerabilities, exposures, and risks to better be prepared and livable for all persons "through environmentally sound urban and territorial planning, infrastructure and basic services" [65].

Author Contributions: Conceptualization, T.M.; methodology (case study), S.P.; validation, S.P.; investigation, S.P.; resources, S.P.; writing—review and editing, T.M., S.P.; supervision, T.M. All authors have read and agreed to the published version of the manuscript.

Funding: This research received no external funding.

Informed Consent Statement: Not applicable.

Conflicts of Interest: The authors declare no conflict of interest.

\section{References}

1. Kourtit, K. Planet of Cities, by Shlomo Angel. 2012. Cambridge, MA: Lincoln Institute of Land Policy. $341+$ xvi. J. Reg. Sci. 2014, 54, 161-162. [CrossRef]

2. Eduardo, M.; van der Arno, Z. Sustainable and Integrated Urban Planning and Governance in Metropolitan and Medium-Sized Cities. Sustainability 2020, 12, 5976.

3. Gibbs, D.C.; Longhurst, J.; Braithwaite, C. Struggling with sustainability': Weak and strong interpretations of sustainable development within local authority policy. Environ. Plan. A 1998, 30, 1351-1365. [CrossRef]

4. James, P. Urban Sustainability in Theory and Practice; Routledge: New York, NY, USA, 2015.

5. Zenker, S.; Petersen, S. Resident-City Identification: Translating the Customer Relationship Management Approach into Place Marketing Theory. In Proceedings of the Conference Paper, 50th Congress of the European Regional Science Association: Sustainable Regional Growth and Development in the Creative Knowledge Economy, Jönköping, Sweden, 19-23 August 2010.

6. Dril, N.; Galkin, A.; Bibik, N. Applying city marketing as a tool to support sustainable development in small cities: Case study in Ukraine. In Proceedings of the 2nd International Conference Green Cities-Green Logistics for Greener Cities, Szczecin, Poland, 2-3 March 2016.

7. Deffner, A.; Metaxas, T. Is City Marketing Opposed to Urban Planning? The Elaboration of a Pilot City Marketing Plan for the Case of Nea Ionia, Magnesia, Greece. In Proceedings of the 46th Congress of the European Regional Science Association 'Enlargement, Southern Europe and the Mediterranean', Volos, Greece, 30 August-3 September 2006.

8. Metaxas, T. The image of the city as 'good': The creation of a city's promotional package through a strategic framework analysis of city marketing procedure. Trans. Ecol. Environ. 2003, 67, 427-438.

9. Piskóti, I.; Szabolcs, N. Identity and Image in the City Marketing. In Proceedings of the Conference: VII. International Congress on Public and Nonprofit Marketing, Szeged, Hungary, 11-12 June 2008.

10. Amundsen, E.S.; Asheim, G. The Notion of "Sustainable Development". Nord. J. Environ. Econ. 1991, 2, 10-14. 
11. Shah, M.M. Sustainable Development. In Encyclopedia of Ecology; Jørgensen, S.E., Fath, B.D., Eds.; Academic Press: Cambridge, MA, USA, 2008; pp. 3443-3446. ISBN 9780080454054.

12. Espiner, S.; Orchiston, C.; Higham, J. Resilience and sustainability: A complementary relationship? Towards a practical conceptual model for the sustainability-resilience nexus in tourism. J. Sustain. Tour. 2017, 25, 1385-1400. [CrossRef]

13. Ahern, J. From fail-safe to safe-to-fail: Sustainability and resilience in the new urban world. Land Scape Urban Plan. 2011, 100, 341-343. [CrossRef]

14. Romero-Lankao, P.; Gnatz, D.M.; Wilhelmi, O.; Hayden, M.H. Urban Sustainability and Resilience: From Theory to Practice. Sustainability 2016, 8, 1224. [CrossRef]

15. Cartalis, C. Toward resilient cities-A review of definitions, challenges and prospects. Adv. Build. Energy Res. 2013, 8, 259-266. [CrossRef]

16. Bec, A.; Moyle, B.; Moyle, C.-L. Resilient and Sustainable Communities. Sustainability 2018, 10, 4810. [CrossRef]

17. Saunders, W.S.A.; Becker, J.S. A discussion of resilience and sustainability: Land use planning recovery from the Canterbury earthquake sequence, New Zealand. Int. J. Disaster Risk Reduct. 2015, 14, 73-81. [CrossRef]

18. Report of the World Commission on Environment and Development: Brundtland Report "Our Common Future"; UN: New York, NY, USA, 1987.

19. Blowers, A.; Glasbergen, P. 7 The search for sustainable development. Prospect. Environ. Chang. 1995, 1, 163-183. [CrossRef]

20. Robert, K.W.; Parris, T.M.; Leiserowitz, A.A. What is Sustainable Development? Goals, Indicators, Values, and Practice. Environ. Sci. Policy Sustain. Dev. 2005, 47, 8-21. [CrossRef]

21. Kanuri, C.; Aromar, R.; Jessica, E.; Holger, K. Getting Started with the SDGs in Cities. 2016. Available online: https:/ / resources. unsdsn.org/getting-started-with-the-sdgs-in-cities (accessed on 30 August 2021).

22. de Jong, M.; Joss, S.; Schraven, D.; Zhan, C.; Weijnen, M. Sustainable-smart-resilient-low carbon-eco-knowledge cities; making sense of a multitude of concepts promoting sustainable urbanization. J. Clean. Prod. 2015, 109, 25-38. [CrossRef]

23. Sachs, J.D. The Age of Sustainable Development; Columbia University Press: New York, NY, USA, 2015.

24. Chelleri, L.; Aliaksandra, B. Understandings of urban resilience meanings and principles across Europe. Cities 2020, $108,102985$. [CrossRef]

25. Ilgen, S.; Sengers, F.; Wardekker, A. City-To-City Learning for Urban Resilience: The Case of Water Squares in Rotterdam and Mexico City. Water 2019, 11, 983.

26. Salata, K.-D.; Yiannakou, A. The Quest for Adaptation through Spatial Planning and Ecosystem-Based Tools in Resilience Strategies. Sustainability 2020, 12, 5548. [CrossRef]

27. Athanassiou, E.; Karagianni, M.; Kapsali, S. Green and Resilient: Shaping a New Identity for Thessaloniki, Changing Cities, 22-26 June 2015, Porto-Heli (Greece). Available online: https:/ / www.researchgate.net/publication/301888865_Green_and_resilient_ shaping_a_new_identity_for_Thessaloniki (accessed on 10 August 2021).

28. Tóth Balázs, I. Regional economic resilience: Concepts, empirics and a critical review. Misc. Geogr. Reg. Stud. Dev. 2015, 19, 70-75.

29. Walker, B.; Holling, C.S.; Carpenter, S.R.; Kinzig, A. Resilience, Adaptability and Transformability in Social Ecological Systems. Ecol. Soc. 2004, 9, 5. Available online: http://www.ecologyandsociety.org/vol9/iss2/art5/ (accessed on 19 August 2021). [CrossRef]

30. Fernandes, J.A.R.; Chamusca, P. Urban policies, planning and retail resilience. Cities 2014, 36, 170-177. [CrossRef]

31. Capolongo, S.; Rebecchi, A.; Dettori, M.; Appolloni, L.; Azara, A.; Buffoli, M.; Capasso, L.; Casuccio, A.; Oliveri Conti, G.; D'Amico, A.; et al. Healthy Design and Urban Planning Strategies, Actions, and Policy to Achieve Salutogenic Cities. Int. J. Environ. Res. Public Health 2018, 15, 2698. [CrossRef]

32. Simmie, J.; Martin, R. The economic resilience of regions: Towards an evolutionary approach. Camb. J. Reg. Econ. Soc. 2010, 3, 27-43. [CrossRef]

33. D'Amico, A.; Currà, E. The Role of Urban Built Heritage in Qualify and Quantify Resilience. Specific Issues in Mediterranean City. Procedia Econ. Financ. 2014. [CrossRef]

34. ICLEI. "Resilient Cities, Thriving Cities: The Evolution of Urban Resilience", Bonn, Germany. 2019. Available online: https:/ / lib.iclei.org/publications/Resilient-Cities-Thriving-Cities_The-Evolution-of-Urban-Resilience.pdf (accessed on 20 August 2021).

35. Resilient Cities Network. Available online: https://resilientcitiesnetwork.org/ (accessed on 20 August 2021).

36. Harrison, P.; Bobbins, K.; Culwick, C.; Humby, T.-L.; La Mantia, C.; Todes, A.; Weakley, D. Urban Resilient Thinking for Municipalities; University of the Witwatersrand: Johannesburg, South Africa, 2014; p. 15.

37. Davoudi, S.; Shaw, K.; Haider, L.J.; Quinlan, A.E.; Peterson, G.D.; Wilkinson, C.; Fünfgeld, H.; McEvoy, D.; Porter, L. Resilience: A Bridging Concept or a Dead End? "Reframing" Resilience: Challenges for Planning Theory and PracticeInteracting Traps: Resilience Assessment of a Pasture Management System in Northern AfghanistanUrban Resilience: What Does it Mean in Planning Practice? Resilience as a Useful Concept for Climate Change Adaptation? The Politics of Resilience for Planning: A Cautionary Note. Plan. Theory Pract. 2012, 13, 299-333. [CrossRef]

38. Walker, B.; Salt, D. Resilience Thinking. Sustain Ecosystems and People in a Changing World; Island Press: Washington DC, USA, 2006.

39. Holling, C.S. Understanding the complexity of Economic, Ecological, and Social Systems. Ecosystems 2001, 4, 390-405. [CrossRef]

40. Simin, D.; Porter, L. Applying the Resilience Perspective to Planning: Critical Thoughts from Theory and Practice. Plan. Theory Pract. 2012, 13, 306. 
41. Chetty, S. The Case Study Method for Research in Small-and Medium-Sized Firms. Int. Small Bus. J. Res. Entrepreneurship. 1996, 15, 73-85. [CrossRef]

42. Yin, R.K. The Case Study Method as a Tool for Doing Evaluation. Curr. Sociol. 1992, 40, 121-137. [CrossRef]

43. Yin, R.K. Enhancing the quality of case studies in health services research. Health Serv. Res. 1999, 34 Pt 2, $1209-1224$.

44. Francis, M. A Case Study Method for Landscape Architecture. Landsc. J. 2001, 20, 15-29. [CrossRef]

45. Rowley, J. Using case studies in research. Manag. Res. News 2002, 25, 16-27. [CrossRef]

46. Vissak, T. Recommendations for Using the Case Study Method in International Business Research. Qual. Rep. 2010, 15, 370-388.

47. City Resilience Framework, Arup pioneered by Rockefeller Foundation, 2014, updated December 2015. Available online: https: //www.rockefellerfoundation.org/wp-content/uploads/City-Resilience-Framework-2015.pdf (accessed on 30 August 2021).

48. Woodrum, E. Mainstreaming content analysis in social science: Methodological advantages, obstacles, and solutions. Soc. Sci. Res. 1985, 13, 1-19. [CrossRef]

49. Krippendorf, K. Content Analysis. An Introduction to Its Methodology; Sage Publication Inc.: Thousands Oak, CA, USA, 2004.

50. Berelson, B. Content Analysis in Communication Research; The Free Press: Glencoe, IL, USA, 1952; p. 220.

51. Handayania, W.; Fisherb, M.R.; Rudiartoa, I.; Setyonoa, J.S.; Foleyb, D. Operationalizing resilience: A content analysis of flood disaster planning in two coastal cities in Central Java, Indonesia. Int. J. Disaster Risk Reduct. 2019, 35, 101073. [CrossRef]

52. Pickvance, $\mathrm{C}$. The four varieties of comparative analysis: The case of environmental regulation. J. Hous. Built Environ. 2005, 16, 7-28. [CrossRef]

53. Smelser, J.N. Comparative Methods in the Social Sciences; Prentice-Hall: Englewood Cliffs, NJ, USA, 1976.

54. Goodrick, D. Comparative Case Studies: Methodological Briefs_Impact Evaluation No. 9; Unicef: New York, NY, USA, 2014.

55. Huovilaa, A.; Boschb, P.; Airaksinenc, M. Comparative analysis of standardized indicators for Smart sustainable cities: What indicators and standards to use and when? Cities 2019, 89, 141-150. [CrossRef]

56. Lizardo, O. The comparative analysis of organizational forms: Considering field and ecological approaches. In Studying Differences between Organizations: Comparative Approaches to Organizational Research in the Sociology of Organizations; Emerald Group Publishing Limited: Bingley, UK, 2009; Volume 26, pp. 117-151.

57. Portney, K.E. Taking Sustainable Cities Seriously: A comparative analysis of twenty-four US cities. Local Environ. 2002, 7, 363-380. [CrossRef]

58. ESPON. SGPTD Second Tier Cities and Territorial Development in Europe: Performance, Policies and Prospects; Final Report; ESPON \& European Institute of Urban Affairs: Luxembourg, 2012.

59. Rotterdam Resilient Strategy. Available online: https://s3.eu-central-1.amazonaws.com/storage.resilientrotterdam.nl/uploads/ 2017/11/09115607/strategy-resilient-rotterdam.pdf (accessed on 20 August 2021).

60. City of Thessaloniki, Resilient Strategy, “Thessaloniki 2030”. March 2017. Available online: www.thessaloniki.gr (accessed on 21 August 2021).

61. Lu, P.; Stead, D. Understanding the notion of resilience in spatial planning: A case study of Rotterdam, The Netherlands. Cities 2013, 35, 200-212. [CrossRef]

62. World Bank. In Thessaloniki, Waterfront Revitalization Is Key for the City's Growth. 2019. Available online: https://blogs. worldbank.org/sustainablecities/thessaloniki-waterfront-revitalization-key-citys-growth (accessed on 21 August 2021).

63. Pitidis, V.; Coaffee, J. Catalysing Governance Transformations through Urban Resilience Implementation: The Case of Thessaloniki, Greece; Elsevier: Amsterdam, The Netherlands, 2020; Volume 107, p. 102934.

64. Labrianidis, L. The development path of the city since the '80s: Missing opportunities. In Thessaloniki in Verge. The City as a Transformational System; Kritiki Publications: Athens, Greece, 2008; pp. 296-297.

65. New Urban Agenda, Habitat III, UN Habitat 2017. Available online: https://unhabitat.org/about-us/new-urban-agenda (accessed on 22 August 2021). 